\title{
FACTORS INFLUENCING CLINICAL OXYGEN TOXICITY
}

\author{
John W. Bean \\ Department of Physiology, University of Michigan \\ Ann Arbor, Mich.
}

\section{Introduction}

Since the early work of Priestley ${ }^{1}$ and Lavoisier, ${ }^{2}$ it has been recognized, though questioned by many, ${ }^{3}$ that breathing increased concentrations of $\mathrm{O}_{2}$ may have adverse as well as therapeutic effects on animal organisms. The exact mechanism of causation of these adverse reactions-which for want of a better name have been referred to as those of $\mathrm{O}_{2}$ poisoning-is not known. But there are numerous factors which influence its occurrence and severity. If the clinical use of $\mathrm{O}_{2}$ in increased concentrations, especially at high pressure, is to achieve the success which it certainly seems to promise, recognition of its potential dangers and limitations, as well as knowledge of the more important factors which contribute to $\mathrm{O}_{2}$ toxicity, is imperative.

\section{Fundamental Factors Influencing $\mathrm{O}_{2}$ Toxicity}

Fundamentally, the occurrence of this phenomenon is determined by: (1) an intensity factor, i.e., the $\mathrm{O}_{2}$ concentration and (2) a duration factor or length of exposure, and both of these depend on (3) the inconstant and frequently unpredictable susceptibility of the subject. Manifestation of $\mathrm{O}_{2}$ poisoning induced by increased concentrations of $\mathrm{O}_{2}$ at normal atmospheric pressure (OAP) and at higher pressures (OHP), i.e., partial pressures in excess of pure $\mathrm{O}_{2}$ at normal atmospheric pressure (hyperbaric $\mathrm{O}_{2}$ ) have many features in common, but in OHP there are additional manifestations of CNS involvement not usually seen in OAP. Nevertheless, for brevity and convenience, here we shall draw no sharp line of demarcation.

\section{Pulmonary Changes in $\mathrm{O}_{2}$ Toxicity}

The first toxic effects of $\mathrm{O}_{2}$ to be observed were those noted by Priestley ${ }^{1}$ and described by Lavoisier" as an "incendiary" action on the lungs of animals breathing $\mathrm{O}_{2}$ at atmospheric pressure. These pulmonary effects which constitute a major manifestation of $\mathrm{O}_{2}$ toxicity involve capillary and alveolar membrane changes which have been described in considerable detail by numerous investigators over the years. ${ }^{3-6}$ These changes may be so severe that pulmonary function fails and the animal may succumb from what in effect is an asphyxia or an "hyperoxic anoxia." 3 .Fortunately, these changes can be prevented or their severity mitigated by appropriate adjustment of the fundamental factors of intensity and duration.

\section{Inherent Differences in Susceptibility as Factors Influencing $\mathrm{O}_{2}$ Toxicity}

Evidence of pulmonary pathology in $\mathrm{O}_{2}$ toxicity has been limited almost entirely to that in experimental animals, whose susceptibility to pulmonary damage by $\mathrm{O}_{2}$ is much greater than that of man. Indeed, human lungs are so much more resistant to the toxic effect of $\mathrm{O}_{2}$ that it has been said that human lung damage by $\mathrm{O}_{2}$ is negligible. But man is by no means immune to pulmonary damage, either by $\mathrm{OAP}$ or OHP, ${ }^{3,7,8}$ Recent reports ${ }^{9,10}$ indicate that continuous therapeutic administration to man, for as short a time as two days, produces histopathology of capillary congestion and proliferation with capillary tufts projecting 
into alveoli, diffuse fibrosis, edema, and thickening of alveolar membraneschanges not attributable to simple atelectasis.

In addition to species differences in susceptibility, there are also pronounced individual differences, not only in the pulmonary involvement, ${ }^{\tau}$ but also and especially in the CNS effects. Knowledge concerning human tolerance to $\mathrm{O}_{2}$ toxicity is presently limited. Thus, there is urgent need of very careful observation and rigid controls in all therapeutic, clinical, and experimental procedures, and methods of $\mathrm{O}_{2}$ administration must be such as to insure accurate determination of the concentration of $\mathrm{O}_{2}$ actually inhaled if reliable thresholds are to be established. This has not always been the case.

The factor of susceptibility is complicated also by the fact that it differs in different tissues. This is well illustrated by another predominantly vascular manifestation of $\mathrm{O}_{2}$ poisoning, viz., that of retrolental fibroplasia. The retina of the premature infant is particularly susceptible to injury by $\mathrm{O}_{2}$ in concentrations very little above 35 to 40 per cent at atmospheric pressure. ${ }^{11,12}$ Infant lungs are much more resistant than the retina, ${ }^{11}$ but they are not immune to $\mathrm{O}_{2}$ damage. ${ }^{13}$ This relationship is reversed with increasing maturity: the retinal vasculature becomes more resistant that that of the lungs. However, the adult retina, at least in animals, is not entirely immune and may be permanently damaged by exposure to OHP. ${ }^{14}$ Permanent partial loss of visual function in adult chickens and rats has accompanied permanent motor paralysis induced by repeated exposure to $\mathrm{O}_{2}$ at $65 \mathrm{psi}^{15}$ Exposure to OHP causes severe temporary visual disturbances in man, ${ }^{16}$ but apparently no permanent alterations have as yet been reported. Nevertheless, the adult human eye may prove to be quite vulnerable to damage by $\mathrm{OHP}-\mathrm{a}$ fear which has been voiced also by others. ${ }^{17}$ Thus, age is another important factor in determining the reaction to $\mathrm{O}_{2}$ poisoning.

Generally speaking, young individuals are less susceptible to $\mathrm{O}_{2}$ toxicity, especially as manifested by $\mathrm{O}_{2}$ convulsions, than are older ones. Infant rats have shown few or no convulsions in OHP until 18 or 19 days old. This is probably related to the immaturity of the adrenals.

Although the factor of age is of considerable importance in the occurrence of $\mathrm{O}_{2}$ poisoning in man, almost all of the current information on thresholds of $\mathrm{O}_{2}$ toxicity in $\operatorname{man}^{3}$ has been obtained from relatively young healthy adult malesthose chosen for naval and diving training programs. Such select subjects at rest remain relatively free of CNS symptoms in $\mathrm{O}_{2}$ at $3 \mathrm{~atm}$. abs. for exposures of two to three hours duration. But even in such select groups, there is considerable individual variation in susceptibility. ${ }^{16}$ Some investigators ${ }^{19}$ set the period of freedom from CNS reaction at two hours in $\mathrm{O}_{2}$ at $2.8 \mathrm{~atm}$. abs., but 80 per cent of their subjects suffered symptoms after two hours exposure to $\mathrm{O}_{2}$ at $3.4 \mathrm{~atm}$. abs. Others ${ }^{20}$ have held that probably no absolutely safe threshold can be established for all subjects even in a select group, because of the wide individual variation in susceptibility. The state of physical rest of the individual, as well as his emotional state, are important factors which are not always readily controllable.

If it is difficult to set absolutely safe thresholds for select groups of young adult human subjects, one might expect it would be even more difficult, if not impossible, to set absolutely safe thresholds for human patients differing widely in age, physical and mental health, and emotional stability. However, a recent study of volunteers and patients indicates that subjects breathing pure $\mathrm{O}_{2}$ at $3 \mathrm{~atm}$. abs. without a mask are "unlikely" to have symptoms of $\mathrm{O}_{2}$ poisoning for periods of at least one-half hour. ${ }^{21}$ Perhaps one may question whether in some cases the occurrence of some CNS symptoms may not be the price one has to pay for the clinical benefits sought in OHP. 
It is disconcerting, however, that one cannot safely assume that because an individual has been free of symptoms during the period of maintained high pressure, he is "out of the woods," so to speak, and that he will remain so during decompression. Even under rigidly controlled decompression, animals which have been free of reactions during the maintenance of high pressure, not infrequently suffer very severe reactions during and after decompression and great difficulty is sometimes encountered in returning them safely to normal atmospheric pressure. ${ }^{3}$ Ruling out lung rupture, which may result from too rapid decompression where airways have been occluded, gas embolism, bends, or decompression sickness, leaves the cause of this "off effect" as it has been called, a matter of speculation. Apparently, as might be expected from these animal experiments, this "off effect" occurs also in human subjects. ${ }^{21}$

\section{Metabolism as a Factor Influencing $\mathrm{O}_{2}$ Toxicity}

Low temperature has long been recognized as a deterrent to the occurrence of $\mathrm{O}_{2}$ toxicity, whereas an elevation of temperature has the opposite effect. ${ }^{22-24}$ The reason for this is believed to be due largely to the attendant changes in metabolism. Thus, the use of hypothermia in clinical procedures in OHP should diminish the possibility of $\mathrm{O}_{2}$ poisoning as well as reduce $\mathrm{O}_{2}$ consumption.

\section{Thyroid Effects}

Since an elevation of metabolism by various means augments the toxic effects of $\mathrm{O}_{2}{ }^{25}$ thyroid activity becomes another significant factor in $\mathrm{O}_{2}$ toxicity. ${ }^{23,26,27}$ The administration of thyroid or thyroxin in experimental animals results in very pronounced enhancement of $\mathrm{O}_{2}$ toxicity of both OAP and OHP, and thyroidectomy has a deterrent effect. One may reasonably assume that these factors would also be operative in human subjects selected for clinical exposure to OHP; thus, a routine BMR determination might be of help in anticipating a subject's possible tolerance to $\mathrm{OHP}$.

\section{Anesthesia}

It has been known since the demonstration by Paul Bert ${ }^{28}$ that anesthesia induced by a variety of agents ${ }^{3}$ protects against the occurrence of convulsive seizures of $\mathrm{O}_{2}$ poisoning and is essential in many experimental and clinical procedures involving exposures to OHP. But it may be well to emphasize that OHP tends to counteract and lighten various anesthesias. ${ }^{3}$ The protective effect of anesthesia has been attributed, in part, to the attendant lowering of metabolism. ${ }^{29}$ However, it is of special interest that anesthesia (sodium pentabarbital), paradoxical as it may seem, may also potentiate the toxic influence of OHP on the CNS and lead to permanent motor paralyses in animals exposed to $\mathrm{O}_{2}$ at 45 psi in as short a time as 15 min. ${ }^{30}$ These paralyses are apparently identical with those induced in our unanesthetized animals by repeated exposures to $\mathrm{O}_{2}$ at 65 psi with which there was associated cerebral vascular pathology ${ }^{31}$ and permanent visual defect. ${ }^{32}$ However, some investigators, finding no very significant cerebral lesions following less severe exposures to OHP, believe the CNS effects of OHP are entirely functional in nature. ${ }^{33}$ Happily, no permanent CNS effects have as yet been reported in men after exposures to OHP, either in the many experimental procedure ${ }^{34,35}$ or in the extensive clinical procedures initiated and carried out by Boerema and associates at Amsterdam or those of Illingsworth and Smith and associates at Glasgow. 


\section{$\mathrm{CO}_{2}$ and Metabolic Products}

The basic cause of oxygen convulsion-like that of pulmonary damage by $\mathrm{O}_{2}$-is not known. It may be a variable and inconstant combination of several factors. But among these an increase in tissue $\mathrm{CO}_{2}$ and the attendant changes in tissue $p \mathrm{H}$, such as might occur with increased metabolism, are especially important..$^{3,36}$ In this connection it is particularly significant that oxygen convulsions seldom occur either in animals or man in $\mathrm{O}_{2}$ pressures much below $3 \mathrm{~atm}$. abs. At this $\mathrm{O}_{2}$ pressure and above there is sufficient extra $\mathrm{O}_{2}$ dissolved in the plasma to supply the ordinary needs of the tissues. Thus, the oxyhemoglobin is not normally reduced, and as a result, the blood loses a large part of its buffer capacity. ${ }^{3,36,37}$ This interferes with the normal carriage of $\mathrm{CO}_{2}$ by the blood and results in an increase in the tissue $\mathrm{CO}_{2}$ and acidity. ${ }^{38-40}$ Although this elevation in tissue $\mathrm{CO}_{2}$ has been shown to be less ${ }^{37}$ than has been claimed by some authors, ${ }^{41,42}$ it assumes very considerable significance. For it has been shown by numerous investigators that low concentration of $\mathrm{CO}_{2}$, which under normal conditions is innocuous (e.g., such as might be present in the patient's mask), has peculiarly toxic effects in the presence of $\mathrm{O}_{2}$ in concentrations above 3 atm. $3,34,36,38,39,43$ This emphasizes a fact of great general importance in OHP, viz, that it is not safe to assume that the effect of a drug or biological agent when administered in OHP should be exactly the same as that induced when administered under normal conditions. This implies the need of pharmacological studies in OHP.

The influence of $\mathrm{CO}_{2}$ and $\mathrm{O}_{2}$ poisoning is complicated further, because, among other things, of its well-known dual action, i.e., of excitation and depression. ${ }^{44,45}$ The toxicity of $\mathrm{O}_{2}$ at $3 \mathrm{~atm}$. and above is augmented by $\mathrm{CO}_{2}$ in its lower concentrations (about five per cent of one atm.), ${ }^{3,36,43,44,46}$ whereas in higher concentrations (e.g., about 16 per cent), it eliminates $\mathrm{O}_{2}$ convulsions but not death..$^{34,40,43}$ This seemingly "protective" influence of $\mathrm{CO}_{2}$, as it is sometimes called, might better be designated as a $\mathrm{CO}_{2}$ depression or $\mathrm{CO}_{2}$ narcosis. Thus, in clinical application of $\mathrm{OHP}$, any elevation in tissue $\mathrm{CO}_{2}$, whether of endogenous or exogenous origin, should be given careful consideration. The administration of OHP or even OAP to an hypercapneic animal or man may complicate the situation by severe depression of respiratory control.

But where there is an anoxic component in $\mathrm{O}_{2}$ poisoning or where surgical procedures involving anoxia are carried out under $\mathrm{O}_{2}$ at high pressure, the presence of $\mathrm{CO}_{2}$ (e.g., two per cent in exposures to $\mathrm{O}_{2}$ at $3 \mathrm{~atm}$. abs. may well be advantageous, ${ }^{47,48}$ because $\mathrm{CO}_{2}$ counteracts the influence of anoxia. ${ }^{45,49}$ Both the augmentative and inhibitive effects of $\mathrm{CO}_{2}$ in toxicity are, in part, at least attributable to the influence of $\mathrm{CO}_{2}$ on the cerebral vasculature and blood flow.

The finding that Tris buffer [tris(hydroxymethyl) aminomethane] or THAM (an efficacious in vivo buffer for hypercapneic acidosis) ${ }^{50}$ affords an appreciable degree of protection against the various aspects of $\mathrm{O}_{2}$ poisoning by $\mathrm{OHP}^{51,52}$ (FIGURE 1), including that of lung damage ${ }^{51}$ (FIGURE 2), reemphasizes the importance of tissue $\mathrm{CO}_{2}$ and acidity, which have long been stressed as important contributory factors in the causation of the toxic action of OHP:8,39

\section{Endocrines}

The endocrine system provides a host of factors which influence $\mathrm{O}_{2}$ toxicity, as demonstrated in experimental animals. The stress of $\mathrm{O}_{2}$ toxicity induces hypertrophy of the hypophysis and the typical stress reaction in the adrenal cortex, ${ }^{53}$ 


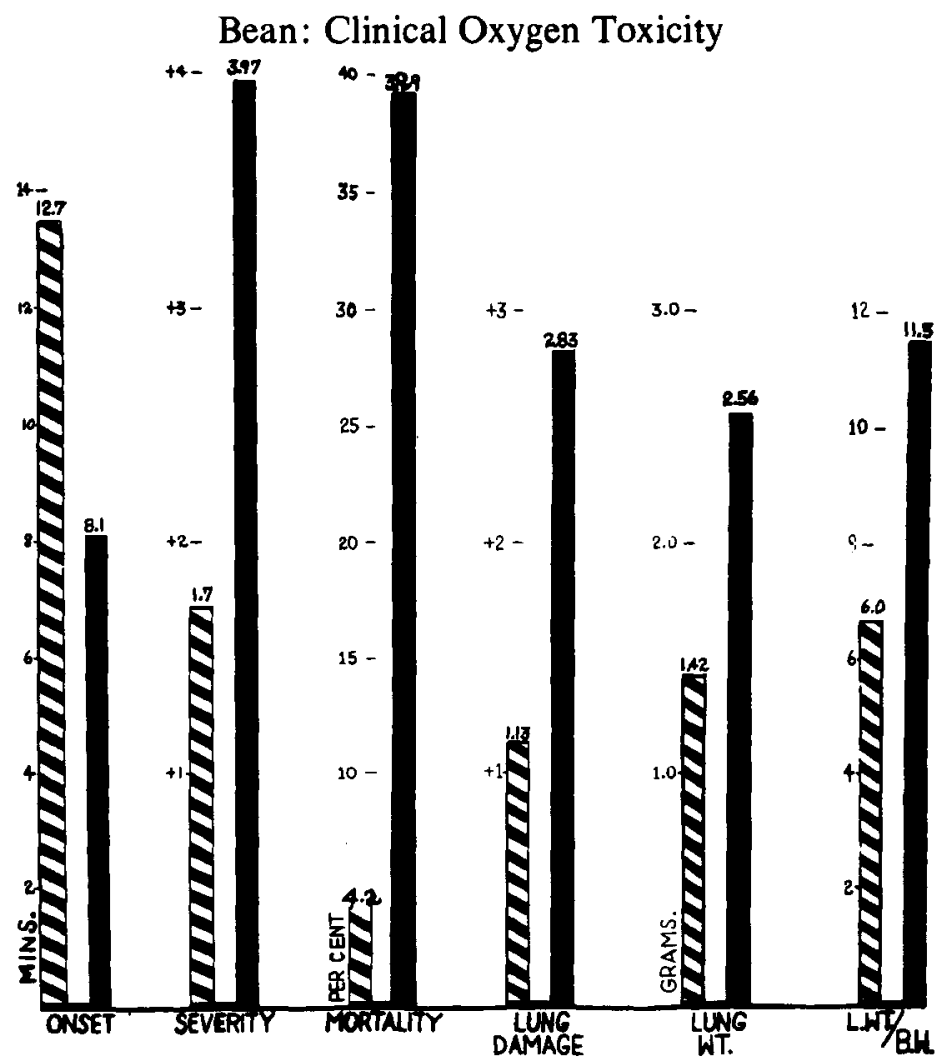

FIGURE 1. Protective action of Tris (THAM) against toxic action of OHP as determined by time of onset of seizures, severity, mortality, lung damage, lung weight, and lung weight/ body weight ratio. The crossmatched column represents the Tris-treated rat, the solid column, the control. Both test and controls were exposed to OHP together.

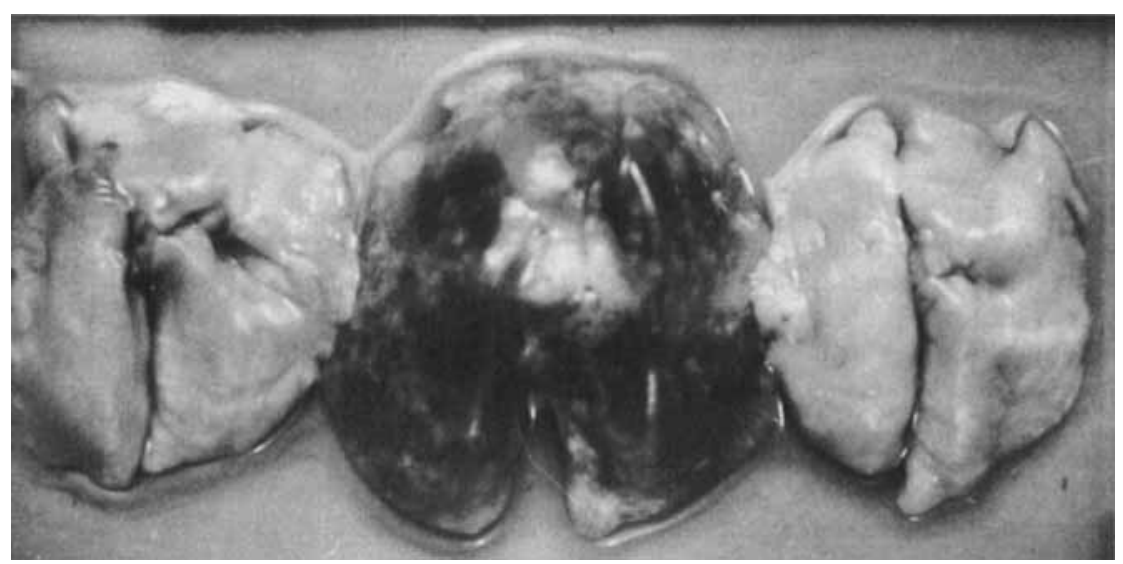

Figure 2. Protective action of Tris (THAM) buffer against pulmonary damage by OHP. (Left, TOHP) Lungs from test rat treated with Tris before exposure to OHP; (center, SOHP) lungs from control injected with saline before exposure, both rats exposed to OHP together; (right, $T, A i r$ ) lungs from rat injected with Tris and kept in air at atmospheric pressure. 


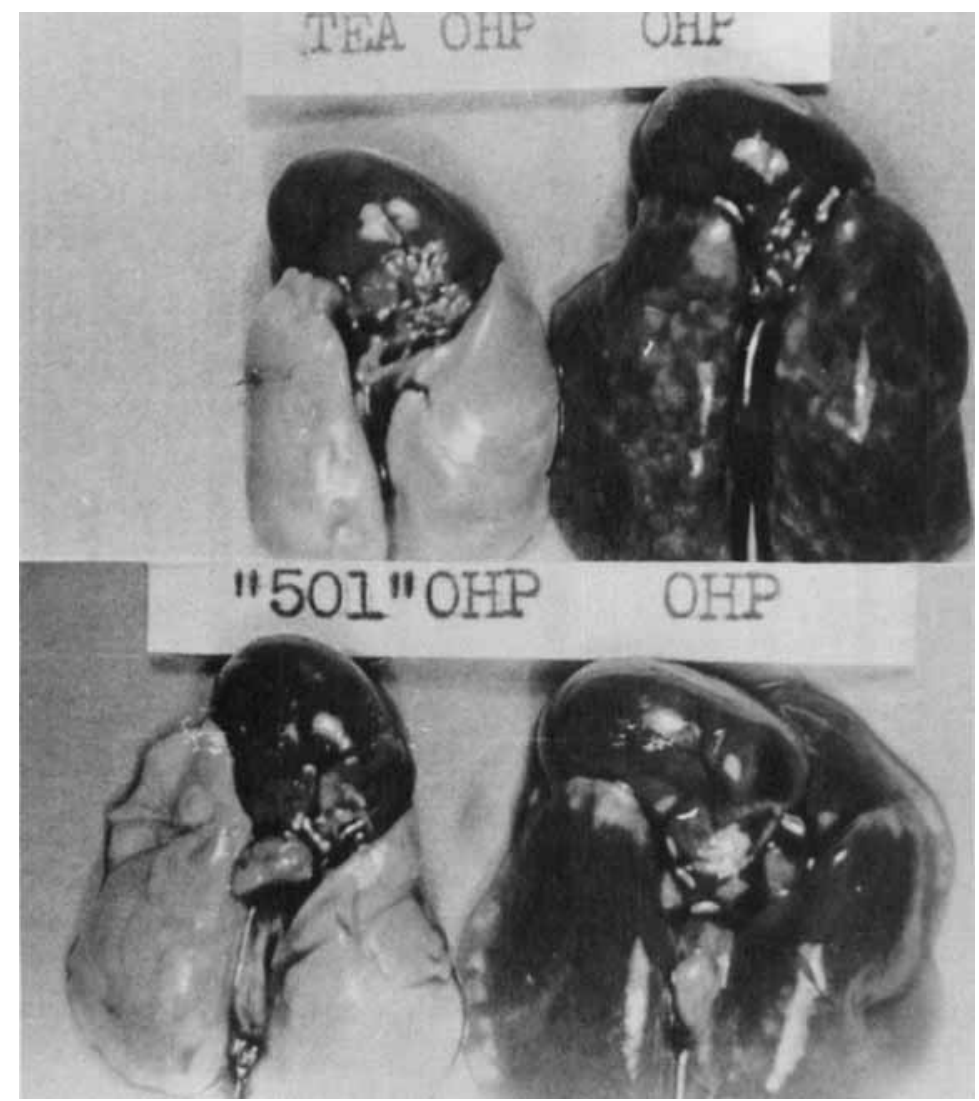

FIGURE 3. Protection against toxic action of OHP on lungs by sympathetic blocking agents: $(a, t o p)$ by TEA; $(b$, bottom $)$ by SKF501. In each case the lungs from the test animal are on the left. Both the test and control animals were exposed to OHP together. Essentially, similar effects are induced by Hexamethonium, Dibenamine, and Dibenzylene.

but, contrary to expectation, it was found that hypophysectomy ${ }^{54}$ and adrenalectomy ${ }^{55,56}$ each provides protection against the toxic action of OHP and in accord with this, cortisone augments it. ${ }^{57,58}$ Thus, the hypophyseal-adrenocortical axis, which serves as a "hormone" defense mechanism against the usual types of stress, actually becomes a liability in the stress of OHP and its increased activity augments rather than diminishes the severity of $\mathrm{O}_{2}$ toxicity.

Similarly, the sympatho-adrenomedullary axis, which serves as another defense mechanism (nervous) against the usual types of stress, becomes something of a liability in the stress of OHP. ${ }^{5 y}$ That this is so is shown by the finding that sympathetic blocking agents (TEA, SKF501,* Dibenamine ${ }^{\circledR}$, Dibenzylene ${ }^{\circledR}$, Hexamethonium) protect against the toxic action of OHP (FIGURES $3 a$ and $3 b$ ) by: (1) diminishing the release of epinephrine which augments $\mathrm{O}_{2}$ toxicity ${ }^{59}$ and (2) by blocking sympathetic nerves to blood vessels. Thus, the vascular damage

* $\mathbf{N}$-(9-fuorenyl)-N-ethyl- $\beta$-chlorethylamine. 
by OHP appears to be mediated, in large part, by the sympathetics. The fact that such sympathetic blocking agents prevent, in large measure, the pulmonary damage by OHP suggests that this damage is largely of neurogenic origin. ${ }^{B 0}$ The combined hypophyseal-adrenocortical and sympatho-adrenomedullary axes, which serve as defense in the usual types of stress but augment the stress of $\mathrm{O}_{2}$ toxicity, are diagramed in FIGURE 4. Chlorpromazine, an effective depressant of the higher centers of the sympathetics which has been found to afford a very pronounced measure of protection against the various aspects (FIGURE 5) of $\mathrm{O}_{2}$ toxicity in experimental animals, ${ }^{81}$ is also a valuable adjunct in the clinical use of OHP. ${ }^{62}$

Thus, neuroendocrine factors have a very significant influence in $\mathrm{O}_{2}$ toxicity relating possibly to: (1) the cause of the wide, individual variation in the susceptibility and unpredictability of reaction to OHP; (2) the emotional and temperamental state of the subjects and patients selected for exposure to OHP; and (3) in the selection of medication, if any, to be used in the clinical application of such exposures. If then one could determine just what factors are responsible

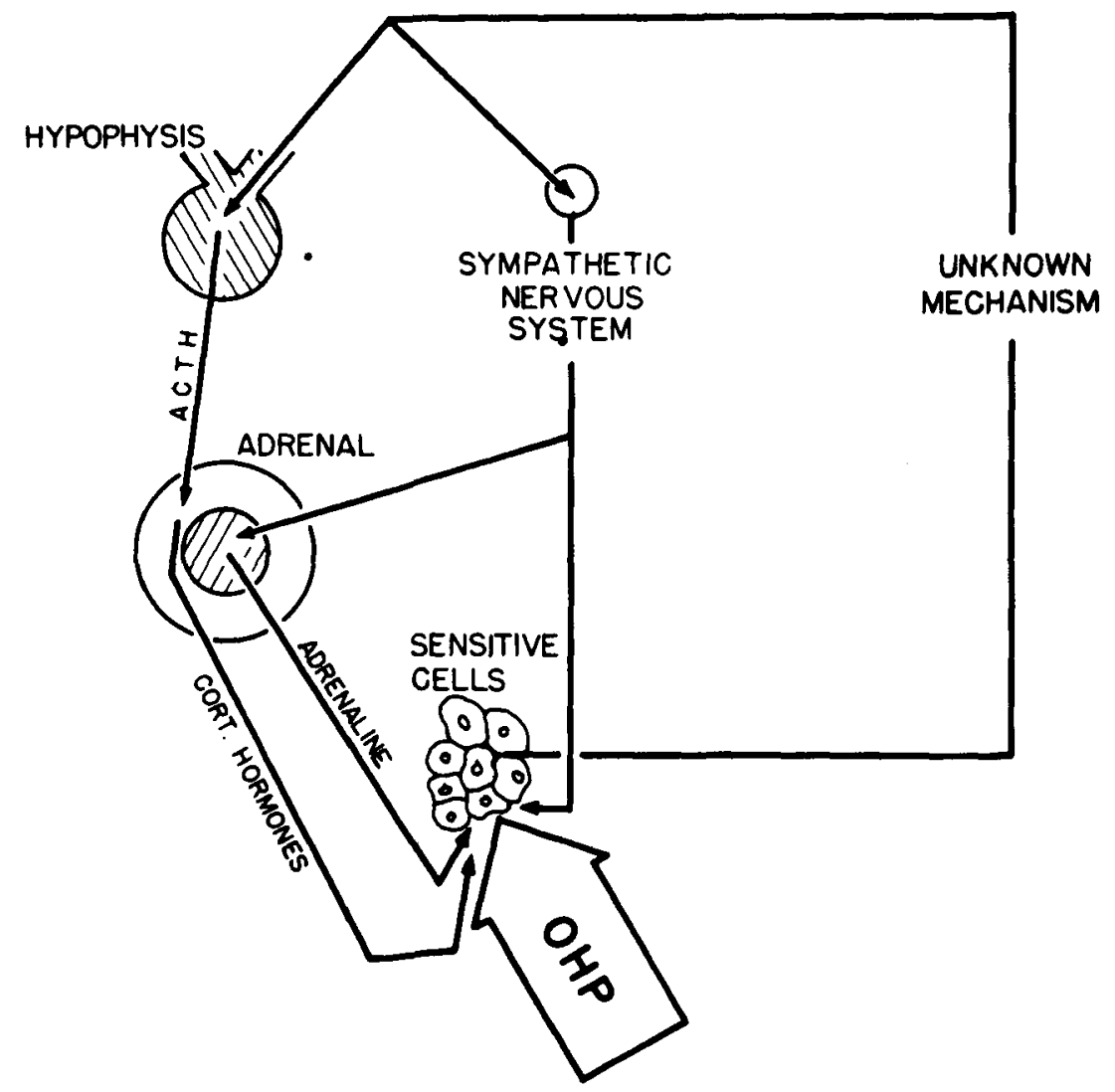

FiguRE 4. Diagrammatic representation of combined hypophyseal-adrenocortical and the sympatho-adrenomedullary "defense" mechanisms, each of which enhances the toxic reaction to the stress of OHP (diagram by P. C. Johnson). 


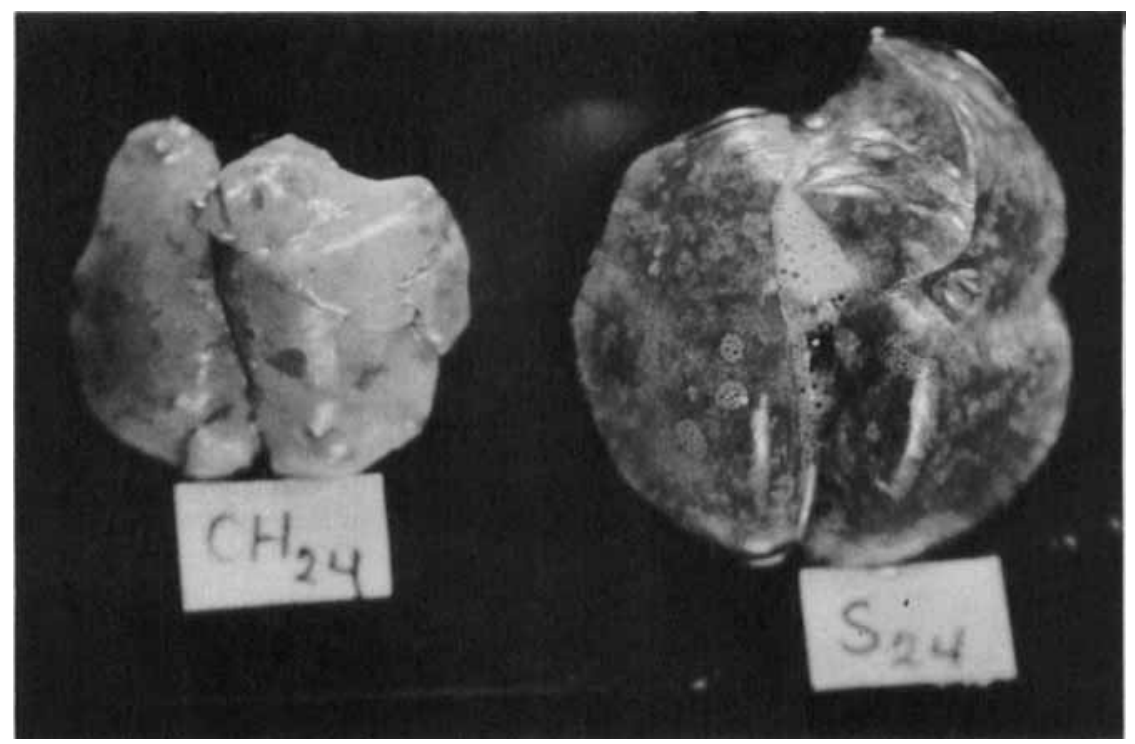

FIGURE 5. Protection against toxic action of OHP on lungs by chlorpromazine (Thorazine $\left.{ }^{\circledR}\right)$. Lungs from test animal $\left(\mathrm{CH}_{24}\right)$ on the left; lungs from the control (saline, $\mathrm{S}_{34}$ ), on the right; both animals exposed to OHP together.

for the wide and inconstant individual variation in susceptibility to $\mathrm{O}_{2}$ poisoning, it would help immeasureably in an understanding of the fundamental mechanisms of its causation.

\section{Factors of Changing Cerebral Blood Flow and $\mathrm{O}_{2}$ Tension}

Still other major factors influencing clinical $\mathrm{O}_{2}$ toxicity are changes in brain blood flow and cerebral $\mathrm{O}_{2}$ tension. But currently there are no entirely satisfactory means of determining absolute values of $\mathrm{O}_{2}$ tension in cerebral tissue. There is evidence ${ }^{35}$ that in unanesthetized men exposed to $\mathrm{O}_{2}$ at $3.5 \mathrm{~atm}$. the mean $\mathrm{pO}_{2}$ of mixed venous brain blood and inferentially that of cerebral tissue, is not much, if any, above normal levels. This has been attributed to cerebral vasoconstriction ${ }^{35}$ which occurs in breathing $\mathrm{O}_{2}{ }^{37,63,64}$ But the finding of minute bubbles in blood after its withdrawal to atmospheric pressure from the superior sagittal sinus of anesthetized dogs exposed to $\mathrm{O}_{2}$ at pressures of 3.5 to $6 \mathrm{~atm}$. abs., together with polarographic evidence, suggests that in such exposures, the $\mathrm{pO}_{2}$ of brain tissue itself, as well as that of circulating sagittal sinus blood, rises well above normal levels, despite the cerebral vasoconstriction. ${ }^{65-67}$

The enhancement of the toxic action of OHP by $\mathrm{CO}_{2}$ in respired $\mathrm{O}_{2}$ may well be due, in large part, to its cerebral vasodilatatory effect. ${ }^{64,68}$ Such addition of $\mathrm{CO}_{2}$ causes a pronounced elevation in $\mathrm{pO}_{2}$, not only of mixed venous brain blood, ${ }^{37,65}$ but also in the cerebral tissue itself, as indicated by polarographic recordings from both anesthetized and unanesthetized animals. ${ }^{65-67}$

Simultaneous recordings from several regions of the brain of either anesthetized or unanesthetized animals exposed to OHP have shown well-pronounced elevations in brain tissue $\mathrm{O}_{2}$. But in unanesthetized animals, superimposed upon 

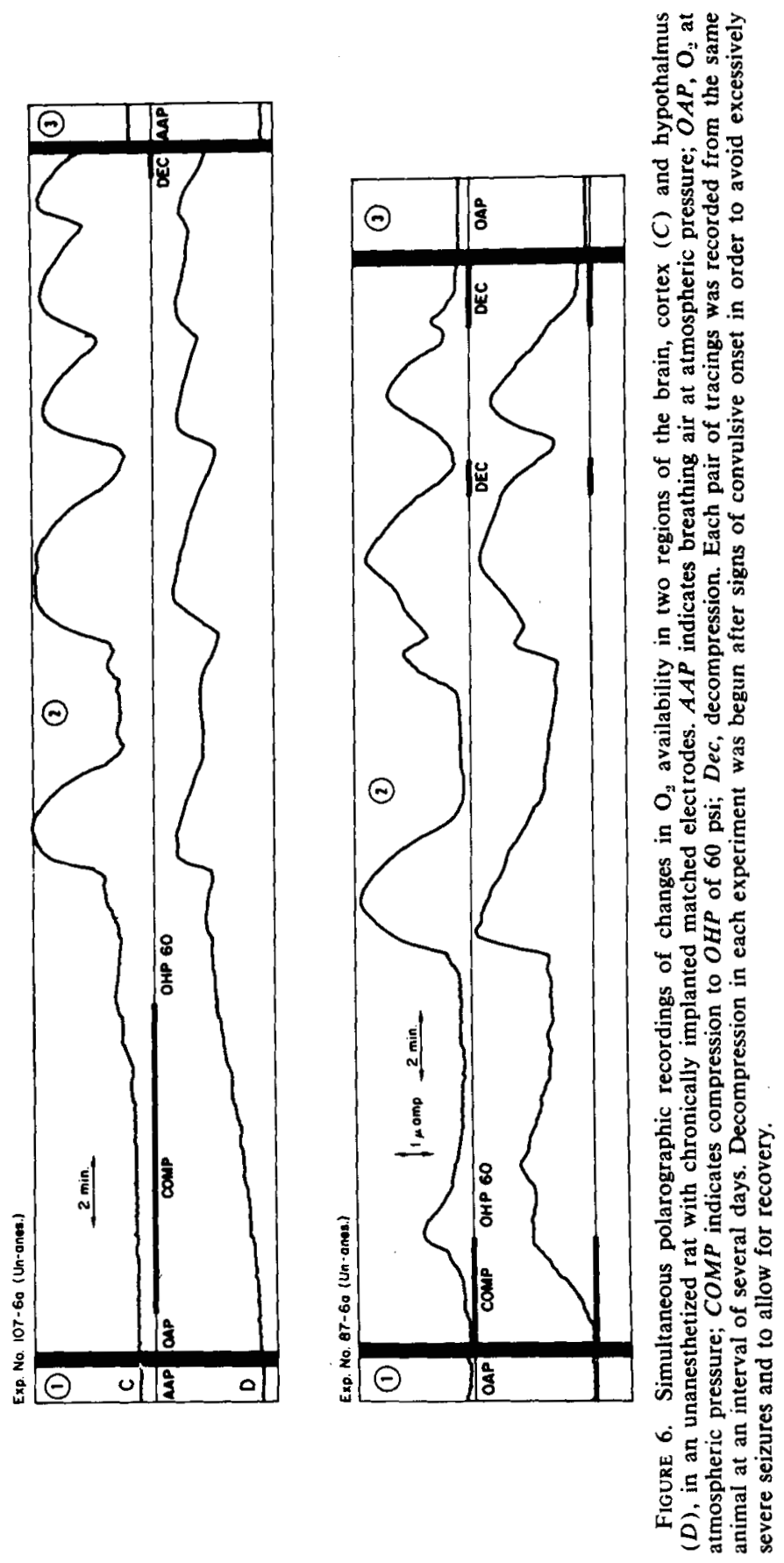
this general elevation in brain $\mathrm{pO}_{2}$, fluctuations appear, which usually increase in magnitude and may culminate in precipitous cyclic elevations frequently associated with overt convulsive seizures. These fluctuations commonly differ in different parts of the brain at any one time, and have been tentatively ascribed to regional changes in brain blood flow and metabolism ${ }^{65,63}$ (FIGURE 6). It may be inferred that there are attendant equally transient and asynchronous regional changes in brain $\mathrm{pCO}_{2}, \mathrm{pO}_{2}$, and $\mathrm{pH}$ which are masked in mixed venous brain blood. Thus, it would appear that in the unanesthetized animal and probably in man exposed to OHP, there are wide regional asynchronous swings in brain blood flow associated with wide regional swings in $\mathrm{pO}_{2}, \mathrm{pCO}_{2}$, and $\mathrm{pH}$, all of which are important factors influencing the reaction of the animal as a whole in $\mathrm{O}_{2}$ poisoning.

\section{References}

1. Priestley, J. 1906. Alembic Club Reprints. No. 7. Univ. Chicago Press. Chicago, Ill.

2. Lavoisier, A. L. 1783. Soc. Roy. Med. (Paris) 5: 569.

3. Bean, J. W. 1945. Physiol. Rev, 25 : 1.

4. SMITH, L. 1899. J. Physiol. 24: 19.

5. Cedergren, B., L. Gyllensten \& J. Wersall. 1959. Acta Paediat. 48: 477.

6. VAN DEN Brenk, H. A. S. \& D. Jamieson. 1962. Australian J. Exptl. Biol. 40: 37.

7. Becker-Freyseng, H. G. \& H. Clamann. 1939. Klin. Wochschr. 18: 1382.

8. Lee, W. L., P. B. Caldwell \& H. S. Schildkraut. 1963. Federation Proc. 22 : 305.

9. Pratt, P. C. 1958. Am. J. Pathol. 34: 104.

10. Gable, W. D. \& F. M. Townsend. 1962. Aerospace Med. 33: 1343.

11. Patz, A. 1957. Pediatrics 19: 509.

12. Ashton, N., G. WARD \& G. Serpell. 1954. Brit. J. Ophthalmol. 38: 394.

13. Gyllensten, L. J. \& B. E. Hellström. 1954. Acta Pediat. Suppl. 100. 43 : 131.

14. Noell, W. K. \& W. H. Baker. 1957. Am. J. Physiol. 87: 584.

15. Bean, J. W. \& E. C. Siegfried. 1945. Federation Proc. 4: 6.

16. Behnke, A. R., H. S. Forbes \& E. P. Motley. 1936. Am. J. Physiol. 144 : 436.

17. Brown, I. 1963. An. Surg. 158: 360 .

18. BeAN, J. W. \& R. BAUER. 1951. Unpublished data.

19. Yarbrough, D. D., W. Welham, E. S. Britton \& A. R. Behnke. 1947. Project X-337 Sub No. 62). Rept. No. 1. Experimental Diving Unit. Naval Gun Factory. Washington, D. C.

20. Donald, K. W. 1947. Brit. Med. J. $1: 667$.

21. Foster, C. A. \& 1. Churchill-Davidson. 1963. J. Appl. Physiol. $18: 492$.

22. Campeell, J. A. 1937. J. Physiol. 89: 17.

23. Grossman, M. S. \& K. W. Penrod. 1949. Am. J. Physiol. 156: 182.

24. Williams, C. M. \& H. K. Beecher. 1944. Am. J. Physiol. 140: 556.

25. Campbell, J. A. 1937. J. Physiol, $90: 91$.

26. Bean, J. W. \& R. Bauer. 1952. Proc. Soc. Exptl. Biol. Med. 81 : 693.

27. Smith, C. W., J. W. Bean \& R. Bauer. 1960. Am. J. Physiol. 199: 883.

28. Bert, P. 1878. La Pression Barometrique. G. Masson. Paris, France.

29. Campeell, J. A. 1939. Libro Homenagem. : 89. A. Ozario de Almeida. Rio de Janeiro, Brazil.

30. JAMIESON, D. \& H. A. S. VAN Den Brenk. 1962. Nature 194: 777.

31. Bean, J. W. 1945. Proc. Soc. Exptl. Biol. Med. 58: 21.

32. Bean, J. W. 1945. Federation Proc. 4: 6.

33. Edström, J. E. \& H. Rockert. 1962. Acta Physiol. Scand. 55: 255.

34. Shaw, L. A., A. C. Messer \& A. R. Behnke. 1934. Am. J. Physiol. 108: 652.

35. Lambertsen, C. J., J. H. Ewing, R. H. Kough, R. Gould \& M. W. Stroud. $1955 . \quad$ J. Appl. Physiol, 8: 255.

36. Gesell, R. 1923. Am. J. Physiol. 66: 5 .

37. Lambertsen, C. J., R. H. Kough, D. Y. Cooper, G. L. Emmel, H. H. Loeschke \& C. F. SchimidT. 1953. J. Appl. Physiol. 5: 471.

38. Bean, J. W. 1929. Proc. Soc. Exptl. Biol. Med. 26: 832.

39. Bean, J. W. 1931. J. Physiol, 72: 27.

40. Behnke, A. R., L. A. Shaw, C. W. Shilling, R. M. Thomson \& A. C. Messer. 1934. Am. J. Physiol. 107: 13.

41. Taylor, H. J. 1949. J. Physiol. 109: 272. 
42. Campbell, J. A. 1930. J. Physiol. 68: 7.

43. Marshall, J .R. \& C. J. Lambertsen. 1955. J. Appl. Physiol. 183: 662.

44. Sмith, C. W. \& J. W. Bean. 1955. Am. J. Physiol. $183: 662$.

45. Gellhorn, E. 1956. Foundations of Neurology and Psychiatry. : 43. U. Minn. Press. Minneapolis, Minn.

46. Chapin, J. 1955. Proc. Soc. Exptl. Biol. Med. 90 : 663.

47. Meijne, N. G., D. M. E. Vermuelen-Cranch, M. E. Suyter, S. J. P. Eloff, L. Schripsema, L. Deen, G. Schoemaker \& I. Boerema. 1962. J. Thoracic Surg. 44: 749.

48. Richards, V., D. Pinto \& P. Coombs. 1963. Ann. Surg. 158: 349.

49. Gibbs, F. A., E. L. Gibbs, W. G. Lennox \& L. F. Nims. 1943. J. Aviation Med. 14: 250.

50. Nahas, G. G., E. C. Jordon \& J. C. Ligou. 1959. Am. J. Physiol. 197: 1308.

51. BeAn, J. W. 1961. Am. J. Phsyiol. 201 : 737.

52. Sanger, C., G. G. Nahas, A. R. Goldberg \& G. M. D'Alessis. 1961, Ann. N. Y. Acad. Sci. $92: 710$.

53. Bean, J. W. 1951. Federation Proc. 10: 11.

54. Bean, J. W. 1952. Am. J. Physiol. 170: 508.

55. Gerschman, R. \& W. O. Fenn. 1954. Am. J. Physiol. 176: 6.

56. Bean, J. W., P. Johnson \& C. W. Smith. 1953. XIX Intern. Physiol. Congr. Abst. : 945.

57. Bean, J. W. \& C. W. Smith. 1952. Am. J. Physiol. I72: 169.

58. TAYlor, D. W. 1953. XIX Intern. Physiol. Congr. Abst. : 821.

59. Bean, J. W. \& P. C. Johnson. 1955. Am. J. Physiol. 180: 438.

60. Johnson, P. C. \& J. W. Bean. 1957. Am. J. Physiol. 188: 593.

61. Bean, J. W. 1956. Am. J. Physiol. 187: 389.

62. Churchill-Davidson, I., C. Sanger \& R. H. Thomlinson. 1957. Brit. J. Radiol. $30: 405$.

63. Gibbs, F. A., E. A. Gibbs \& W. G. Lennox. 1935. Am. J. Physiol. 111: 557.

64. KeTY, S. S. \& C. F. SCHMidT. 1948. J. Clin. Invest. $27: 484$.

65. BeAn, J. W. 1961. Am. J. Physiol. 201 : 1192.

66. Bean, J. W. \& L. Sullivan. 1962. Physiologist 5: 104.

67. Jamieson, D. \& H. A. S. Van den Brenk. 1963. J. Appl. Physiol. 18: 869.

68. LennoX, W. G. \& E. L. GibBs. 1932. J. Clin. Invest. 11: 1155. 